\title{
Correlation between the immunohistochemical expressions of MMP-1, MMP-7 and VEGF and prognostic factors in colorectal adenocarcinoma ${ }^{1}$
}

\author{
Correlação entre as expressões imunohistoquímicas da MMP-1, MMP-7 e do VEGF no \\ adenocarcinoma colorretal com fatores prognósticos
}

\author{
Edmundo Guilherme de Almeida Gomes', Mário Jorge JucáII, Hunaldo Lima de Menezes ${ }^{\mathrm{III}}$, Benício Luiz Bulhões Barros Paula \\ Nunes $^{\mathrm{IV}}$, Henrique Costa ${ }^{\mathrm{V}}$, Flávio de Oliveira Lima ${ }^{\mathrm{VI}}$, Delcio Matos ${ }^{\mathrm{VII}}$
}

I PhD, Assistant Professor, of Surgery, School of Medicine, Federal University of Alagoas, Brazil.
II Associate Professor of Surgery, School of Medicine, Federal University of Alagoas, Brazil.
III MSc, Attending Physician in the General Surgery Unit, Hospital Arthur Ramos, Alagoas, Brazil.
IV MSc, Attending Physician, Coloproctology Unit, Hospital Santa Casa de Maceio, Alagoas, Brazil.
${ }^{\text {V }} \mathrm{PhD}$; Assistant Professor of Pathology,Health Sciences State University of Alagoas, Brazil
VI PhD, Attending Physician, Pathology Unit, Hospital Santa Casa de Avare, Sao Paulo, Brazil.
VII Full Professor, Surgical Gastroenterology Division, Department of Surgery, UNIFESP, Sao Paulo, Brazil.

\begin{abstract}
Purpose: To analyze the expression of metalloproteinase-1, metalloproteinase-7 and vascular endothelial growth factor (VEGF) in colorectal adenocarcinoma, and to correlate these with the clinical-pathological prognostic factors. Methods: Tumor tissue from 82 patients was fixed in formalin and embedded in paraffin blocks. These samples were analyzed by means of the streptavidin-biotin immunohistochemical method, using the tissue microarray technique. Marker positivity was evaluated using categorical scores that determined cutoff percentages of stained tumor cells. Protein tissue expression was correlated with the variables of degree of cell differentiation, staging, disease-free interval, recurrence, survival and specific mortality. The Fisher exact and Kaplan-Meier tests were used to assess associations between the markers and the study variables. The log-rank and Wilcoxon tests were used to assess the significance of differences between curves of disease-free interval and survival. Results: All tumors were positive for metalloproteinase-1; $50(61 \%)$ were positive and $32(39 \%)$ were negative for metalloproteinase-7; and $60(74.1 \%)$ were positive and $21(25.9 \%)$ were negative for VEGF. Correlation of marker expression, both in groups and individually, did not show statistical significance in relation to the degree of cell differentiation, staging, disease-free interval, survival or specific mortality. Recurrence showed a statistically significant correlation with positive expression of the three markers, when analyzed as a group $(p=0.038)$. Conclusion: The associated expression of metalloproteinase-1, metalloproteinase-7 and VEGF in colorectal adenocarcinoma is related to the incidence of disease recurrence.
\end{abstract}

Key words: Colorectal Neoplasms. Prognosis. Extracellular Matrix. Tumor Markers, Biological.

\section{RESUMO}

Objetivo: Analisar as expressões da metaloproteinase-1, metaloproteinase-7 e do fator de crescimento endotelial vascular no adenocarcinoma colorretal e correlacionar com os fatores prognósticos clínico-patológicos. Métodos: Foram analisados tecidos fixados em formol e dispostos em blocos de parafina dos tumores de 82 pacientes, por imunohistoquímica, pelo método da estreptavidina-biotina, usando-se a técnica de arranjo em matriz de amostras teciduais (tissue microarray). Na avaliação da positividade dos marcadores foi utilizado um escore categórico, que predeterminou o valor de corte na percentagem de células coradas do tumor. As expressões teciduais das proteínas foram correlacionadas com as varáveis representadas pelo grau de diferenciação celular, estadiamento, tempo livre de doença, recidiva, sobrevida e mortalidade específica. Foram empregados os testes exato de Fisher e de Kaplan-Meier para verificar as associações dos marcadores com as varáveis estudadas. Para testar a significância das diferenças entre as curvas do tempo livre de doença e da sobrevida foram utilizados os testes de longrank e Wilcoxon. Resultados: A metaloproteinase-1 foi positiva em todos os tumores. A metaloproteinase-7 foi positiva em $50(61 \%)$ e negativa em $32(39 \%)$ tumores. O fator de crescimento endotelial vascular foi positivo em $60(74,1 \%)$ e negativo em $21(25,9 \%)$ tumores. A correlação das expressões dos marcadores realizada separadamente e em conjunto não apresentou significância estatística com o grau de diferenciação celular, estadiamento, tempo livre de doença, sobrevida e mortalidade específica. A recidiva apresentou correlação estatística significante com a expressão positiva dos três marcadores, quando foram analisados em conjunto ( $\mathrm{p}=0,038)$. Conclusão: As expressões associadas da metaloproteinase-1, metaloproteinase- $7 \mathrm{e}$ do fator de crescimento endotelial vascular no adenocarcinoma colorretal se relacionam com a incidência de recidiva da doença.

Descritores: Neoplasias Colorretais. Prognóstico. Matriz Extracelular. Marcadores Biológicos de Tumor.

${ }^{1}$ Research performed at Surgical Gastroenterology Division, Department of Surgery, UNIFESP, Sao Paulo, Brazil. 


\section{Introduction}

The capacity of malignant cells to invade other tissues and disseminate to distant organs is a characteristic that very often leads to the host's death. Proteolytic enzymes have a fundamental role in cancer progression, through allowing tumor cells to access the vascular and lymphatic systems that irrigate and sustain tumor growth, thus creating routes for disease dissemination ${ }^{1,2}$. Among the proteolytic enzymes associated with tumor invasion, metalloproteinases have achieved considerable importance due to their ability to cleave components of the extracellular matrix and basal membranes. This allows penetration and infiltration of the underlying stroma by neoplastic cells ${ }^{3}$.

Metalloproteinase-1 (MMP-1) is a collagenase that degrades collagens I, II and III. Elevated expression of MMP-1 was associated with a poor prognosis in colorectal cancer cases ${ }^{4,5}$. This was reaffirmed in another study in which MMP-1 was absent from benign adenomas but presented elevated expression in cases of invasive colorectal carcinomas. Furthermore, there were correlations with the degree of invasion, lymph node involvement and hepatic metastasis 6 .

Metalloproteinase-7 (MMP-7), named matrilysin, is expressed in $90 \%$ of colonic adenocarcinomas ${ }^{7}$. The clinical impact of its presence in colorectal cancer cases has been evaluated, and increases in its expression have been associated with the presence of lymph node and distant metastases ${ }^{8}$. However, this enzyme seems to induce angiogenesis, thus stimulating the proliferation of vascular endothelial cells and the formation of new vessels adjacent to the colorectal tumor, which facilitates metastatic dissemination ${ }^{9}$.

The formation of new blood vessels from preexisting vessels, i.e. angiogenesis, is essential for the growth of solid tumors larger than 1 or $2 \mathrm{~mm}^{3}$, in which the oxygen diffusion, per se, does not attain sufficient distance to maintain an adequate level in the tissue ${ }^{10}$. Angiogenesis is a complex process that depends on the local balance between the proangiogenic and antiangiogenic molecules that are released from neoplastic cells and also on the host, including the immunological cells and adjacent stroma ${ }^{11}$. The vascular endothelial growth factor (VEGF), basic fibroblastic growth factor (bFGF), platelet-derived endothelial cell growth factor (PD-ECGF), angiopoietins, thrombospondins and ephrins are factors with angiogenic potential ${ }^{12}$.

The two initial events of great importance in metastasis formation are the tumor cell proliferation and the creation of an extensive network of vessels from preexisting vessels. Neoplastic cells must invade the extracellular matrix and penetrate into the blood and lymph vessels. The invasion process is helped by decreased cell adhesion, increased cell mobility and secretion of enzymes that degrade the extracellular matrix, such as metalloproteinases, cathepsins and plasminogen activators ${ }^{13}$. High VEGF expression in colorectal adenocarcinoma cases has been associated with increased numbers of vessels in the invasive margins of tumors and with cell proliferation and distant metastases ${ }^{14}$. Another study found an inverse relationship between VEGF expression and survival, thus confirming that invasive colorectal cancer is dependent on angiogenesis ${ }^{15}$.

Clinical studies have suggested that elevated expression of proteins relating to the cell cycle, angiogenesis and cell invasion-migration may have prognostic significance for colorectal adenocarcinoma cases. Therefore, the presence of markers in tumors that are studied needs to be correlated with the clinical-pathological characteristics, to enable identification of tumor groups with specific phenotypes and similar clinical results, so that they can be considered to have prognostic value ${ }^{16}$.

The present study analyzed the immunohistochemical expressions of MMP-1, MMP-7 and VEGF in colorectal adenocarcinoma cases and determined the correlations between this group of tumor markers and the clinical-pathological prognostic factors.

\section{Methods}

The analysis included 82 patients who underwent surgical resection of colorectal adenocarcinoma at Hospital Sao Paulo, between 2001 and 2005. This study had been granted prior approval by the Research Ethics Committee of the Federal University of São Paulo. Tumor samples were fixed in formalin and processed routinely using the paraffin-embedding method. Histological thin sections were stained using hematoxylin-eosin and were reviewed by three pathologists to confirm the diagnosis. Immunohistochemical analysis was performed on the samples by means of the tissue microarray (TMA) technique. The international classification for malignant tumors (TNM), as adopted by the International Union against Cancer (UICC), was used for tumor staging.

The study sample consisted of 44 females (53.7\%) and 38 males $(46.3 \%)$. The ages ranged from 29 to 89 years, with a mean of 59 years. The follow-up ranged from six to 64 months, with a mean of 35 months. Tumor location, urgency of the surgery, degree of cell differentiation and staging are shown in Table 1.

\section{Immunohistochemistry}

The tumor samples were sliced into sections of $4 \mu \mathrm{m}$ in thickness, and the adhesive tape system (Instrumedics Inc., Hackensack, NJ, USA) was used to mount the slices on TMA blocks. The paraffin was removed from the slides using xylol and alcohol. Antigen recovery was performed for all the antibodies, except for MMP-7. This process was carried out in a Pascal pressure chamber in a citrate solution with $\mathrm{pH} 6$ at $125^{\circ} \mathrm{C}$, lasting for 30 seconds after reaching $125^{\circ} \mathrm{C}$ and a pressure of between 20 and 25 psi. The sample was then left to cool at room temperature for 20 minutes. After washing in running water for 5 minutes, endogenous peroxidase was blocked by means of 10 volumes of hydrogen peroxide for 5 minutes, followed by washing with PBS buffer at $\mathrm{pH}$ 7.4. A protein blockade was performed using a protein blocker (DaKoCytomation), with sample immersion for 20 minutes.

For the immunohistochemical reaction using the streptavidin-biotin method, the following primary antibodies were used: anti-VEGF monoclonal antibody (Clone VG-1) (DaKoCytomation), diluted to 1:200; anti-MMP-1 polyclonal antibody Ab-6 (NeoMarkers), diluted to 1:400; and anti-MMP-7 antibody Ab-1 (Clone ID2) (NeoMarkers), diluted to 1:1200. The primary antibodies used for metalloproteinase identification recognize both the active and the latent types. For the 
amplification system, NovoLink polymer (Novocastra) was used, with a 30-minute incubation period, followed by washing with PBS buffer. The reaction was developed performed using the 3,3 diaminobenzidine chromogen (Liquid DAB + Substrate Chromogen System Kit, DaKoCytomation, Carpinteria, California), for 5 minutes, followed by washing in running water. The slide was counterstained with Harris hematoxylin for 2 minutes and washed in running water for 5 minutes. It was then dehydrated with alcohol and washed with xylol, for subsequent mounting of cover slips using Entellan resin (Sigma).

The positive pattern for primary antibodies is the appearance of a chestnut-brown color in the cell cytoplasm. Slides containing histological sections that had previously been shown to be positive were used as positive controls, and slides with primary antibody subtraction during an immunochemical reaction were used as negative controls.

The criteria used for evaluating the MMP-1, MMP-7 and VEGF markers were based on the use of categorical scores that determined cutoff percentages of stained tumor cells Cases with values greater than $10 \%$ were considered positive, while those with values less than $10 \%$ were considered negative. The three evaluators read the slides independently and did not have access to the clinical data on the patients.

\section{Statistical analyses}

The Fisher exact test was used to analyze the tissue expression of tumor markers in relation to separate and grouped associations with the variables of degree of cell differentiation, staging, recurrence and specific death.

The Kaplan-Meier life table method was used to compare the tissue expression of tumor markers in relation to separate and grouped associations with disease-free interval and survival. The log-rank and Wilcoxon (Breslow version) tests were used to assess the significance of any differences in the curves for disease-free interval and survival. For the analyses performed, the limit of $\mathrm{p}<0.05$ was established for rejection of the null hypothesis, and the values considered to be statistically significant were highlighted.

TABLE 1 - Clinical-pathological characteristics of the tumors

\begin{tabular}{llll}
\hline \multicolumn{1}{c}{ TUMOR CHARACTERISTICS } & & $\mathrm{N}$ & PERCENTAGE \\
\hline \multirow{2}{*}{ Tumor location } & R Colon & 35 & 42.7 \\
& L Colon & 19 & 23.2 \\
& Rectum & 26 & 31.7 \\
& Synchronic & 2 & 2.4 \\
\hline \multirow{2}{*}{ Urgency of surgery } & Elective & 67 & 81.7 \\
& Emergency & 15 & 18.3 \\
\hline \multirow{2}{*}{ Degree of differentiation } & Low degree & 78 & 95.1 \\
& High degree & 4 & 4.9 \\
\hline \multirow{2}{*}{ Staging } & I & 10 & 12.2 \\
& II & 32 & 39.0 \\
& III & 26 & 31.7 \\
& IV & 14 & 17.1
\end{tabular}

R - Right L - Left 


\section{Results}

The TMA block presented the loss of a few tissue samples. The marker expression analysis showed that all the tumors were positive for metalloproteinase-1; 50 tumors $(61 \%)$ were positive and $32(39 \%)$ were negative for metalloproteinase-7; and 60 tumors $(74.1 \%)$ were positive and $21(25.9 \%)$ were negative for VEGF (Figure 1).

The degree of cell differentiation did not show any correlation with the expressions of MMP-1, MMP-7 $(p=0.16)$ or VEGF $(p=0.7)$, or with the three markers together $(p=0.32)$. Staging did not show any correlation with the expressions of MMP-1, MMP-7 $(p=0.72)$ or VEGF $(p=0.78)$, or with the three markers together $(p=0.66)$. Disease-free interval did not show any correlation with the expressions of MMP-1, MMP-7 $(\mathrm{p}=0.068)$ or VEGF $(p=0.128)$, or with the three markers together $(p=0.089)$. Disease recurrence did not show any correlation with the expressions of MMP-1, MMP-7 $(p=0.83)$ or VEGF $(p=0.32)$, but the three markers in association showed a statistically significant difference $\left(\mathrm{p}=0.038^{*}\right)$ with this variable (Table 2 ). Survival did not show any correlation with the expressions of MMP-1, MMP-7 ( $p=0.628)$ or VEGF $(p=0.561)$, or with the three markers together $(p=0.503)$. Specific mortality did not show any correlation with the expressions of MMP-1, MMP-7 $(p=0.43)$ or VEGF $(p=0.4)$, or with the three markers together $(p=0.43)$. The overall results from this investigation are shown in Table 3.

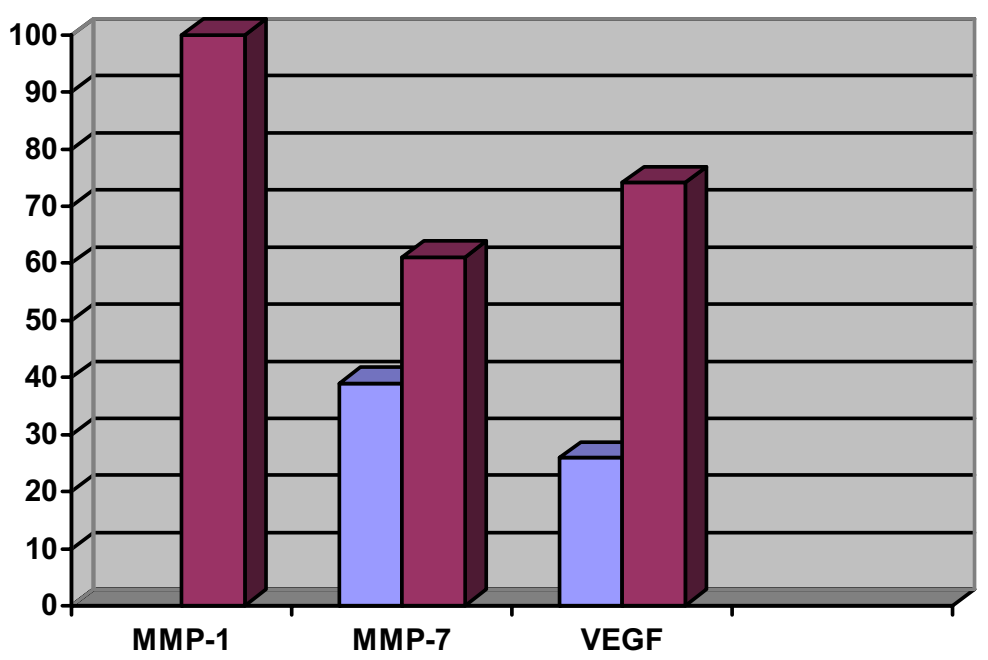

\section{$\square$ Negative \\ a Positive}

FIGURE 1 - Distribution of tumor expressions of MMP-1, MMP-7 and VEGF

TABLE 2 - Distribution of separate and grouped expressions of MMP-1, MMP-7 and VEGF in relation to tumor recurrence

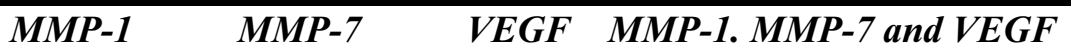

$n(\%) \quad n(\%) \quad n(\%) \quad n(\%)$

Positive

$18(100)$

$8(44.4)$

12(66.7)

$5(27.8)$

Negative

$0(0.0)$

$10(55.6)$

$6(33.3)$

13(72.2)

$\begin{array}{lllll}\text { Total } & 18(100) & 18(100) & 18(100) & 18(100)\end{array}$

$$
\mathrm{n}=\text { number }(\%)=\underset{\text { percentage }}{\mathrm{p}} \mathrm{p}=0.83 \quad \mathrm{p}=0.32 \quad \mathrm{p}=0.038^{*}
$$


TABLE 3 - Distribution of results for tumor expression of MMP-1, MMP-7 and VEGF in relation to the clinical and pathological variables analyzed

\begin{tabular}{|c|c|c|c|c|c|c|c|c|c|c|c|c|c|c|}
\hline \multirow{2}{*}{ Variables } & \multicolumn{3}{|c|}{ MMP-1 } & \multicolumn{3}{|c|}{ MMP-7 } & \multirow[t]{2}{*}{$\begin{array}{l}\mathbf{p} \\
\text { value }\end{array}$} & \multicolumn{3}{|c|}{ VEGF } & \multirow[t]{2}{*}{$\begin{array}{l}\text { p } \\
\text { value }\end{array}$} & \multicolumn{2}{|c|}{$\begin{array}{l}\text { MMP-1. MMP-7 } \\
\text { and VEGF }\end{array}$} & \multirow[t]{2}{*}{$\begin{array}{l}\mathbf{p} \\
\text { value }\end{array}$} \\
\hline & $\mathbf{P}$ & $\mathbf{N}$ & TOTAL & $\mathbf{P}$ & $\mathbf{N}$ & TOTAL & & $\mathbf{P}$ & $\mathbf{N}$ & TOTAL & & $\mathbf{P}$ & TOTAL & \\
\hline
\end{tabular}

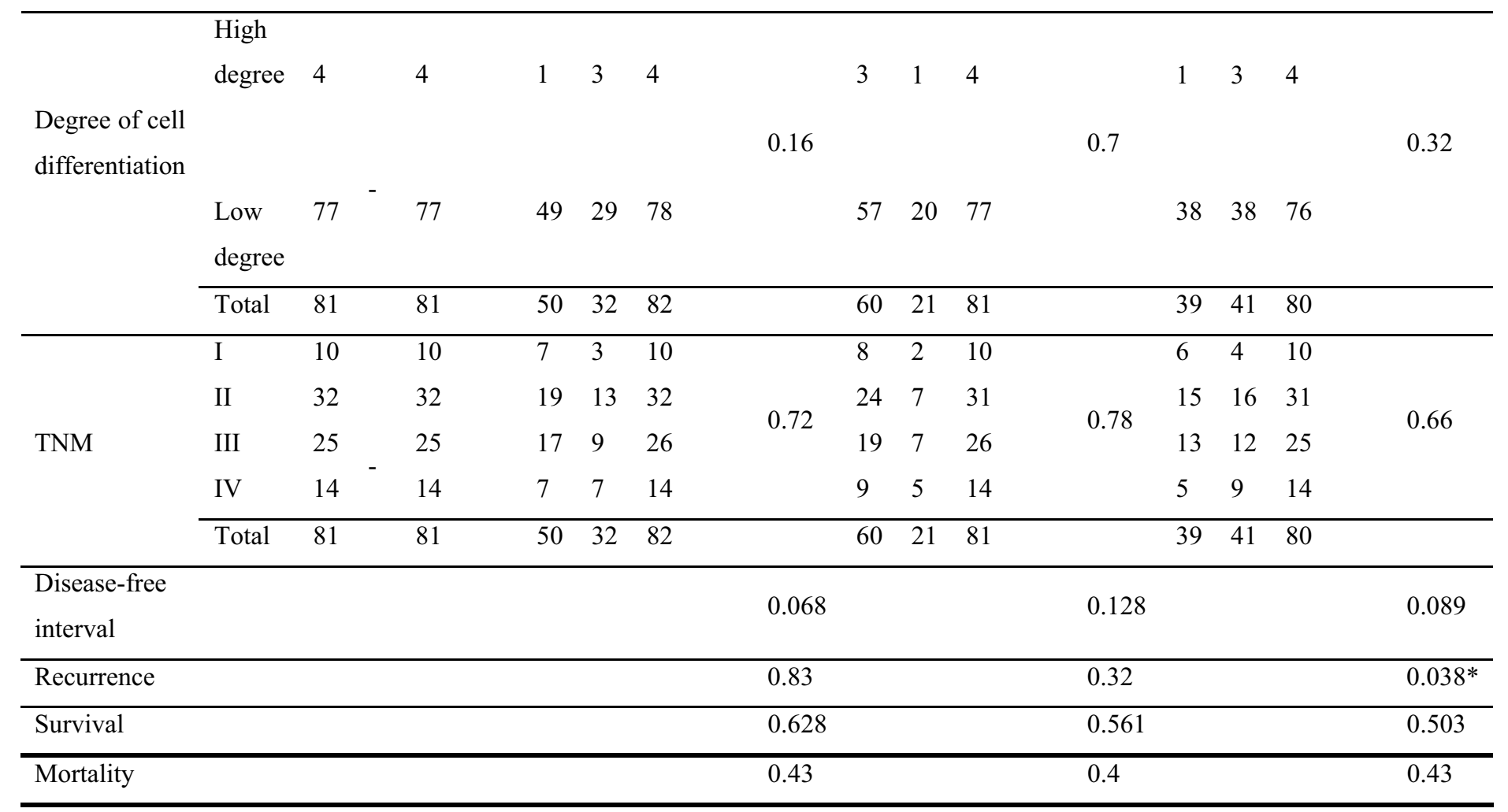

$\mathrm{P}=$ positive $\mathrm{N}=$ negative

\section{Discussion}

Prognostic markers are variable that provide prospective information regarding patient success, i.e. they complement the staging data obtained by pathologists and may guide therapeutic decisions ${ }^{17}$. At present, histopathological confirmation of adequate excision and tumor staging, which assess tumor invasion into the intestinal wall and the presence of metastases to the lymph nodes, are the basic staging methods used for prognostic guidance. However, it is widely recognized that tumors of the same pathological stage may produce considerably different clinical results and, consequently, it is necessary to identify other factors that influence prognosis, independent of tumor staging ${ }^{16}$.

The proteins investigated in this study are markers for cell invasion-migration and for angiogenesis, and they have important roles in the gradual development of the tumor. Previous reports had suggested that these proteins could be used as prognostic markers for colorectal cancer. The analysis on this group of markers has determined that these molecules have reciprocal action and shown their prognostic relevance. Metalloproteinases are crucial for angiogenesis, since they degrade the extracellular matrix, thus creating space for endothelial cell migration. On the other hand, they release growth factors, among them VEGF, which are linked to the extracellular matrix, and these recruit pericytes from the preexisting vessels in order to create new blood vessels that will be responsible for the growth of the neoplasm and for metastatic dissemination ${ }^{18}$.

The initial event in colorectal carcinogenesis is the mutation of the suppressor gene APC, in up to $80 \%$ of human tumors. This event leads to the loss of gene function and subsequent decreased production of the APC protein, which is responsible for degradation of $\beta$-catenin. Accumulation of this protein in the cytoplasm and nucleus of the cell, through the WNT signaling pathway, starts the nuclear transcriptional activity, thereby resulting in the expression of target genes, such as those for MMP-7. This phenomenon has been observed in cell cultures from human colorectal adenocarcinoma, and it could explain the increased expression of MMP-7 in colorectal cancer ${ }^{19}$.

MMP-7 seems to influence cell migration in colonic carcinoma through the cleavage of the $\beta 3$ chain of laminin-5, an important component of the epithelial basal membrane, thus reinforcing the role of metalloproteinases in tumor progression ${ }^{20}$. On the other hand, an experimental investigation has associated MMP-7 with angiogenesis, through the observation that new blood vessels were produced adjacent to cell cultures of human colon adenocarcinoma, with increased expression of MMP-7, when the cells were implanted in the dorsum of mice. In animals with cell implants that were treated with a specific MMP-7 blocker, there was no induction of blood vessel formation?. 
The capacity of a tumor to invade the intestinal wall and produce metastases depends on angiogenesis. This gives rise to an extensive network of capillary vessels to provide nutrition for the neoplasm and creates the conditions for cancer cells to enter the bloodstream and form secondary foci in distant organs ${ }^{21}$. Analysis of VEGF RNAm expression in colorectal cancer and its relationship with clinical characteristics has shown that increased expression of VEGF RNAm in the tumor presents a significant correlation with the degree of invasion depth in the intestinal wall, and with distant and lymph node metastases ${ }^{22}$.

MMP-1 has a key role in the lysis of collagens I and III, which are the main components of the gastrointestinal tract stroma. Cleavage of these structural components allows invasion of neoplastic cells into the intestinal wall. This MMP-1 activity is more intense in the initial stages of local tumor invasion. Increased MMP-1 expression has shown a statistically significant correlation with the presence of involved lymph nodes at the time of diagnosis and metachronic metastases, thus suggesting that this enzyme participates in the dissemination of colorectal cancer ${ }^{23}$. In the present study, when the positive expression of this proteinase was analyzed separately, there was no association between it and the previously mentioned variables.

In the present study, the immunohistochemical expressions of MMP-1, MMP-7 and VEGF were analyzed in colorectal tumors, and the results obtained were further correlated with the main clinical-pathological prognostic factors, i.e. the degree of cell differentiation, staging, disease-free interval, recurrence, survival and specific mortality. None of these factors was shown to be separately or jointly associated with the markers, except for recurrence. When all three markers were analyzed together, positive expression of these markers showed a statistically significant correlation with recurrence, in comparison with negative expression, thus suggesting that there is a molecular profile relating to disease prognosis.

With regard to the degree of cell differentiation, the present study did not show any association with MMP-1 expression. This result was similar to findings by some other authors ${ }^{24}$. On the other hand, this association was shown to be statistically significant in another investigation ${ }^{25}$. MMP-7 did not show any correlation in this respect, like in other reports ${ }^{26,27,28}$. VEGF did not correlate with this variable, and this finding is corroborated by another study ${ }^{29}$, although there was a statistically significant association with the degree of tumor differentiation in stage II (TNM) in the study by Cascinu et al. ${ }^{30}$ and in undifferentiated neoplasms in another report ${ }^{31}$.

When the marker expression was correlated with staging, there was no association with MMP-1. This was also observed in the study by Sunami et al. ${ }^{32}$, who used the Dukes classification. On the other hand, other authors who used the same staging method as in the present study found statistically significant correlations $s^{4,6,25}$. MMP-7 was not associated with staging in the present study, and a similar result was found in the study by Schwandner et al. ${ }^{28}$, who used the TNM classification. However, increased expression of this enzyme showed correlations with disease staging in other studies that used the Dukes classification ${ }^{8,27}$. There was no correlation between VEGF and staging in the present study, and this result was compatible with what was observed by Shu et al. ${ }^{31}$, who also used the TNM staging method. However, Nakasaki et al. ${ }^{29}$ found a statistically significant correlation between the expression of this protein and the Dukes classification.
MMP-1 expression in tumors did not show any statistically significant correlation with disease-free interval in the present study, and this was similar to the result presented by Bendardaf et al. ${ }^{23}$. However, the expression of this enzyme was positive in all tumors in another report, in which the patients were divided into two groups named low expression and high expression. Disease-free survival in that study was significantly higher among individuals who presented low MMP-1 expression, in comparison with those who had high expression ${ }^{32}$. MMP-7 expression in tumors in the present investigation was not associated with this clinical characteristic, and the literature consulted did not present data on this variable. VEGF expression in tumors in the present study did not correlate with disease-free survival, and this finding is corroborated in the report by Kekec et al. ${ }^{33}$. However, a meta-analysis carried out by Des Guetz et al. ${ }^{15}$ found a statistically significant correlation between positive expression of VEGF and decreased disease-free interval, thus reinforcing the importance of this growth factor for disease progression.

When analyzing the association of MMP-1 and MMP-7 expression with recurrence, the present study did not show any statistical significance, and this result was similar to that of other studies $^{24,26}$. In the present study, VEGF expression did not show correlation any with this variable, in the same way as found in the analysis carried out by Kekec et al. ${ }^{33}$. On the other hand, many authors have reported a strong correlation between positive expression of VEGF and disease recurrence, thereby classifying patients with such characteristics as presenting a high risk of disease recurrence ${ }^{30,34,35}$. Nonetheless, when the three markers were assessed as a group for correlation with disease recurrence, the result found in the present study was statistically significant, thus suggesting that the presence of this set of markers increases the risk of tumor recurrence.

In the present study, MMP-1, MMP-7 and VEGF expression did not show any statistically significant correlations with survival when analyzed either separately or as a group. Bendardaf et $a l .{ }^{23}$ found a similar result when analyzing MMP-1 expression in colorectal tumors, and this a finding has been corroborated by other two studies that used larger groups of markers, among which MMP-1 and MMP-7 ${ }^{16,24}$. However, Murray et al. $^{4}$ observed statistical significance between high MMP-1 expression in tumors and survival. Regarding VEGF, the results obtained in the present study are different from those of other researchers who studied this variable, since they reported that increased expression of this marker was strongly associated with decreased survival ${ }^{33,35}$. Reinforcing this hypothesis, a meta-analysis concluded that VEGF expression had an inverse, statistically significance relationship with survival ${ }^{15}$.

In the present sample, 16 individuals died as a result of the disease, but the markers did not present a statistically significant correlation with specific mortality, either separately or as a group. No reports in the literature consulted used this variable as a prognostic indicator in analyzing correlations with MMP-1, MMP-7 and VEGF expression in colorectal tumors.

Several prognostic markers for colorectal cancer have been described in immunohistochemical investigations that analyzed single or small groups of molecules, which are the correct manner to proceed for the initial evaluation of possible markers. The results obtained were conflicting, since the studies were carried out among populations with small numbers of individuals, 
including all disease stages, with inadequate follow-up duration and within a restricted biological context. The inclusion of all disease stages makes the analysis inappropriate for answering this question and dilutes the statistical power of the study. Stage I has little potential for clinical applicability and stage IV is associated with the tumor response to therapy, or is applicable for observing the quality of life among these patients. To evaluate the clinical usefulness of a marker, it is necessary to assess a large number of well-characterized patients, belonging to a specific disease stage, and over a long follow-up period. Thus, if there is a clear association between the factor and the clinical outcomes under observation, the study will provide a trustworthy result, with high statistical power ${ }^{17}$.

The present study analyzed three molecular markers within two biological contexts and found an association between the immunohistochemical expressions of MMP-1, MMP-7 and VEGF in colorectal adenocarcinoma and disease recurrence. However, other studies need to be devised in order to prove the consistency of this association, using a well-defined group of individuals, with a larger number of markers that are involved in a wide variety of biological functions, and with a higher statistical power. Therefore, the results from the present study and the findings in the literature make it possible to conclude that, so far, there is insufficient evidence to justify the use of the tumor expression of these molecular markers in clinical practice.

\section{Conclusion}

The associated expression of metalloproteinase-1, metalloproteinase-7 and VEGF in colorectal adenocarcinoma is related to the incidence of disease recurrence.

\section{References}

1. Chambers AF, Groom AC, McDonald IC. Metastasis: dissemination and growth of cancer cells in metastatic sites. Nature. 2002;2:563-72.

2. Mareel M, Leroy A. Clinical, cellular, and molecular aspects of cancer invasion. Physiol Rev. 2003;83:337-76.

3. Brinckerhoff CE, Matrisian LM. Matrix metalloproteinases: a tail of a frog that became a prince. Nature. 2002;2:207-14.

4. Murray GI, Duncan ME, O’Neil P, Melvin WT, Fothergill JE. Matrix metalloproteinase-1 is associated with poor prognosis in colorectal cancer. Nature Med. 1996;2(4):461-2.

5. Jucá M, Nunes BLBBP, Menezes HL, Gomes EGA, Matos D. Metalloproteinases 1 e 7 e câncer colorretal. Rev Bras Coloproctol. 2008;28(3):353-62.

6. Shiozawa J, Ito M, Nakayama T, Nakashima M, Kohno S, Sekine I. Expression of matrix metalloproteinase-1 in human colorectal carcinoma. Mod Pathol. 2000;13(9):925-33.

7. Newell KJ, Witty JP, Rodgers WH, Matrisian LM. Expression and localization of matrix-degrading metalloproteinases during colorectal tumorigenesis. Mol Carcinog. 1994;10(4):199-206.

8. Adachi Y, Yamamoto H, Itho F, Hinoda Y, Okada Y, Imai K. Contribution of matrilysin (MMP-7) to the metastatic pathway of human colorectal cancers. Gut. 1999;45:252-8.

9. Nishizuka I, Ichikawa Y, Ishikawa T, Kamiyama M, Hasegawa S, Momiyama N, Miyazaki K, Shimada H. Matrilysin stimulates DNA synthesis of cultured vascular endothelial cells and induces angiogenesis in vivo. Cancer Lett. 2001;173:175-82.

10. Folkman J. The role of angiogenesis in tumor growth. Semin Cancer Biol. 1992;3(2):65-71.
11. Hanahan D, Folkman J. Patterns and emerging mechanisms of the angiogenic switch during tumorigenesis. Cell. 1996;86:353-64.

12. Ellis LM, Liu W, Ahmad SA, Fan F, Jung YD, Shaheen RM, Reinmuth N. Overview of angiogenesis: Biologic implications for antiangiogenic therapy. Semin Oncol. 2001;28(5 Suppl 16):94-104.

13. Stoeltzing O, Liu W, Reinmuth N, Parikh A, Ahmad AS, Jung YD, Fan F, Ellis LM. Angiogenesis and antiangiogenic therapy of colon cancer liver metastasis. Ann Surg Oncol. 2003;10(7):722-33.

14. Takahashi Y, Kitadai Y, Bucana CD, Cleary KR, Ellis LM. Expression of vascular endothelial growth factor and its receptor, KDR, correlates with vascularity, metastasis, and proliferation of human colon cancer. Cancer Res. 1995;55:3964-8.

15. Des Guetz G, Uzzan B, Nicolas P, Cucherat M, Morere J-F, Benamouzig R, Breau J-L, Perret G-Y. Microvessel density and VEGF expression are prognostic factors in colorectal cancer. Meta-analysis of the literature. $\mathrm{Br}$ J Cancer. 2006;94:1823-32.

16. Lyall MS, Dundas SR, Curran S, Murray GI. Profiling markers of prognosis in colorectal cancer. Clin Cancer Res. 2006;12(4):1184-91.

17. McLeod HL, Murray GI. Tumour markers of prognosis in colorectal cancer. Br J Cancer. 1999;79(2):191-203.

18. Rundhaug JE. Matrix metalloproteinases and angiogenesis. J Cell Mol Med. 2005;9(2):267-85.

19. Brabletz T, Jung A, Dag S, Hlubek F, Kirchner T. B-Catenin regulates the expression of the matrix metalloproteinase-7 in human colorectal cancer. Am J Pathol. 1999; 155:1033-8.

20. Remy L, Trespeuch C, Bachy S, Scoazec J-Y, Rousselle P. Matrilysin 1 influences colon carcinoma cell migration by cleavage of the laminin-5 B3 chain. Cancer Res. 2006;66(23):11228-37.

21. Liekens S, De Clercq E, Neyts J. Angiogenesis: regulators and clinical applications. Biochem Pharmacol. 2001;61:253-70.

22. Ishigami S-I, Arii S, Furutani M, Niwano M, Harada T, Mizumoto M, Mori A, Onodera H, Imamura M. Predictive value of vascular endothelial growth factor (VEGF) in metastasis and prognosis of human colorectal cancer. Br J Cancer. 1998;78(10):1379-84.

23. Bendardaf R, Buhmeida A, Ristamäki R, Syrjänen K, Pyrhönen S. MMP-1 (collagenase-1) expression in primary colorectal cancer and its metastases. Scand J Gastroenterol. 2007;42(12):1473-8.

24. Hilska M, Roberts PJ, Collan YU, Laine VJO, Kössi J, Hirsimäki P, Rahkonen O, Laato M. Prognostic significance of matrix metalloproteinases-1,-2, -7 and 13 and tissue inhibitors of metalloproteinases-1, $-2,-3$ and -4 in colorectal cancer. Int J Cancer. 2007;121:714-23.

25. Baker EA, Bergin FG, Leaper DJ. Matrix metalloproteinases, their tissue inhibitors and colorectal cancer staging. Br J Surg. 2000;87:1215-21.

26. Masaki T, Matsuoka H, Sugiyama M, Abe N, Goto A, Sakamoto A, Atomi Y. Matrilysin (MMP-7) as a significant determinant of malignant potential of early invasive colorectal carcinomas. Br J Cancer. 2001;84(10):1317-21.

27. Hong-zhi L, Zong-guang Z, Lie Y, Yong-yang Y, Cao T, Bing Z, Xue-Lian Z, Qing-jie X, Yuan L, Rong W. Clinicopathologic and prognostic significance of MMP-7 (Matrilysin) expression in human rectal cancer. Jpn J Clin Oncol. 2005;35(12):739-44.

28. Schwandner O, Schlamp A, Broll R, Bruch HP. Clinicopathologic and prognostic significance of matrix metalloproteinases in rectal cancer. Int J Colorectal Dis. 2007;22:127-36.

29. Nakasaki T, Wada H, Shigemori C, Miki C, Gabazza EC, Nobori T, Nakamura S, Shiku H. Expression of tissue factor and vascular endothelial growth factor is associated with angiogenesis in colorectal cancer. Am J Hematol. 2002;69:247-54.

30. Cascinu S, Staccioli MP, Gasparini G, Giordani P, Catalano V, Ghiselli R, Rossi C, Baldelli AM, Graziano F, Saba V, Muretto P, Catalano G. Expression of vascular endothelial growth factor can predict event-free survival in stage II colon cancer. Clin Cancer Res. 2000;6:2803-7. 
31. Shu Z, Ming-Yong H, Zuo-Xiang X, Jia-Ping P, Qi D. Clinical significance of vascular endothelial growth factor expression and neovascularization in colorectal carcinoma. World J Gastroenterol. 2003;9(6):1227-30.

32. Sunami E, Tsuno N, Osada T, Saito S, Kitayama J, Tomozawa S, Tsuruo T, Shibata Y, Muto T, Nagawa H. MMP-1 is a prognostic marker for hematogenous metastasis of colorectal cancer. Oncologist. 2000;5:108-4. 33. Kekec Y, Paydas S, Zorludemir S, Parsak CK, Sakman G, Seydaoglu G. Prognostic significance of vascular endothelial growth factor-A expression in colorectal cancer. J Cancer Mol. 2006;2(4):161-7.

34. Takahashi Y, Tucker SL, Kitadai Y, Koura AN, Bucana CD, Cleary KR, Ellis LM. Vessel counts and expression of vascular endothelial growth factor as prognostic factors in node-negative colon cancer. Arch Surg. 1997;132:541-6.

35. Galizia G, Lieto E, Ferraraccio F, Orditura M, De Vita F, Castellano P, Imperatore V, Romano C, Ciardiello F, Agostini B, Pignatelli C. Determination of molecular marker expression can predict clinical outcome in colon carcinomas. Clin Cancer Res. 2004;10:3490-9.

\section{Correspondence:}

Edmundo Guilherme de Almeida Gomes

Rua Barão José Miguel, 126/601

57055-160 Maceio - AL Brazil

edmundo-gomes@ig.com.br

Conflict of interest: none

Financial source: none

Received: January 21, 2009

Review: March 24, 2009

Accepted: April 28, 2009

\section{How to cite this article}

Gomes EGA, Jucá MJ, Menezes HL, Nunes BLBBP, Costa H, Lima FO, Matos D. Correlation between the immunohistochemical expressions of MMP-1, MMP-7 and VEGF and prognostic factors in colorectal adenocarcinoma. Acta Cir Bras. [serial on the Internet] 2009 July-Aug;24(4). Available from URL: http://www.scielo.br/acb 